\title{
HR-LC-MS based profiling of phytochemicals from methanol extracts of leaves and bark of Myristica dactyloides Gaertn. from Western Ghats of Karnataka, India
}

Kuppuru Mallikarjunaiah Marulasiddaswamy ${ }^{1}$, Bettadapura Rameshgowda Nuthann, ${ }^{2,3}$, Channarayapatna-Ramesh Sunilkumar ${ }^{3}$,

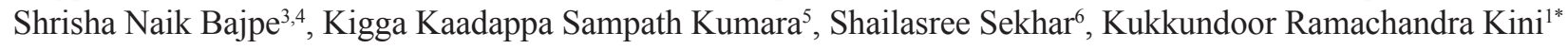

${ }^{1}$ Department of Studies in Biotechnology, University of Mysore, Manasagangotri, Mysuru, India.

${ }^{2}$ Department of Studies in Microbiology, University of Mysore, Manasagangotri, Mysuru, India.

${ }^{3}$ Global Association of Scientific Young Minds, Mysore, India.

${ }^{4}$ Department of Studies in Biotechnology, Shri Dharmasthala Manjunatheshwara College (Autonomous) Ujire, Mangalore, Karnataka, India.

${ }^{5}$ Government Pre-University College, Davangere, Karnataka, India.

${ }^{6}$ Institution of Excellence (IOE), Vijnana Bhavana, University of Mysore, Mysuru, India.

\section{ARTICLE INFO \\ Article history: \\ Received on: April 11, 2021 \\ Accepted on: June 09, 2021 \\ Available online: September 01, 2021}

Key words:

Myristica dactyloides, HR-

LC-MS, antioxidants, anti-

inflammatory, metabolite profiling

\begin{abstract}
Untargeted profiling of phytochemicals from plant extracts would aid in the exploration of various groups of compounds and assist in the identification of new bioactive compounds, reducing the redundancy in compound identification. The potential bioactive phytochemicals present in Myristica dactyloides, an endemic ethnomedicinal plant widely used in traditional treatment practices, were explored and cataloged in this study. The untargeted phytochemical profile of active methanolic leaves and bark extracts was assessed by Ultra high-performance liquid chromatography coupled to electrospray ionization and quadrupole time-offlight mass spectrometry. Preliminary screening results highlighted the high efficiency of methanolic extract as an effective antioxidant and anti-inflammatory agent, along with a remarkable amount of total phenolics and flavonoid content. Thus, the methanolic extracts of leaves and bark samples were further subjected to catalog its chemical constituents through untargeted metabolite profiling. Analysis of high-resolution liquid chromatography-mass spectrometer spectra, exhibited 3,813 and 1,797 molecular features in the ESI+ mode with clean retention time-exact mass, resulted in identifying 35 major therapeutically important common compounds for the first time in both leaves and bark extracts of M. dactyloides, fitting to major groups like lignans, neolignans, phenylpropanoids, diarylnonanoid, flavonoids, and others. Our results prove the presence of Myoinositol, Malabaricone B, Malabaricone C, Malabaricone D, and 1-(2,6-dihydroxyphenyl)9-(4-hydroxy-3-methoxyphenyl) nonan-1-one previously reported from $M$. dactyloides, along with promising chemical signatures like Monotropein, Austrobailignan 7, Fragransol B, Guaiacin, Myricanone, Nectandrin A, Argenteane, and Epicatechin to the phytochemical catalog of $M$. dactyloides. Furthermore, our research not only confirms the existence of previously known molecules and adds new phytochemicals, but it also sheds light on the wide application of $M$. dactyloides for possible bio-prospecting for a new chemical entity.
\end{abstract}

*Corresponding Author

K. Ramachandra Kini, Department of Studies in Biotechnology

Manasagangotri, University of Mysore, Mysore, India.

E-mail: krk@appbot.uni-mysore.ac.in

\section{INTRODUCTION}

The dependence of humans on plants to survive or to treat has been inevitable in the long history of humanity on this planet, as shown by comprehensive documentation. Also, now, plants play an important part in the healthcare system as a treasure for bioactive compounds. The scientific community's dedication to conserving natural treasures has risen as never before, and the current trend is to create sustainable and reliable solutions 
to prevent overexploitation by providing target-specific treatment/isolation of compounds. The concept of distinguishing chemical entities from plants spawned a modern branch of science known as ethnopharmacology, which seeks to separate possible lead drugs from medicinally important plants [1]. Initially, pharmacological researchers in search of new bioactive compounds faced significant technological difficulties in extracting, isolating, and characterizing the compounds. Despite significant obstacles, researchers have been able to address methodological difficulties in characterizing plant metabolites from chemically diverged complex crude mixtures by continuing to work on studying the complex chemistry in plants. This was made possible by researchers advocating for the use of liquid chromatography-mass spectrometry techniques for untargeted phytochemical profiling in recent years [2-5]. Because of its accuracy, sensitivity, speed, and specificity, the ability of liquid chromatography with tandem mass spectrometry to couple with other chromatographic techniques provides many advantages in studying and characterizing the phytoconstituents of medicinal plants. Furthermore, advances in computational bioinformatics techniques and the development of online metabolite databases have made detection easier to an extent but with its limitations $[6,7]$. Plant metabolite characterization using chromatographic methods has advanced in recent decades, contributing significantly to the cataloging of a large number of metabolites from pharmacologically relevant plants. However, there is still a need to use chromatographic-based chemical fingerprinting extensively for a number of medicinally significant plants that have remained unidentified due to traditional extraction and identification procedures.

The current research is one such approach to cataloging and validating the chemical constituents of Myristica dactyloides bioactive potentials. It is a prominent member of the Myristicaceae family, native to India and Sri Lanka, with 18-21 genera and nearly $300-520$ species $[8,9]$. It is listed as vulnerable by the International Union for Conservation of Nature due to its widespread use and exploitation for its wide range of medicinal benefits. Coughs, bronchitis, fever, burning sensations, inflammation of joints, skin disorders, wounds, sleeplessness, indigestion, liver disorders, and worms are all treated with arils [10]. Bark and leaves are used in Ayurvedic preparations and decoctions to treat throat ailments [11]. Various researchers around the world have explored the chemistry and bioactive potentials of a similar species, Myristica fragrans [12]. Despite having the similar pharmacological potential to M. fragrans, $M$. dactyloides has remained unexplored except for a few early attempts [13-17]. In these reports, Myoinositol, Malabaricone A, B, C, D, Dactyloidin, Acylresorcinols, Arylalkanones, and Lignans were found in various parts of the $M$. dactyloides Gaertn.

With this background, the present investigation was carried out to catalog the chemical constituents of $M$. dactyloides using Ultra high-performance liquid chromatography coupled to electrospray ionization and quadrupole time-of-flight mass spectrometry (UHPLC-ESI-QTOF-MS) analysis and to validate their pharmacological significance through in-vitro assays in the context of $M$. dactyloides extracts anti-inflammatory potential. The study emphasizes the importance of early metabolite identification in crude extracts to prevent redundancy in the characterization of new bioactive compounds in drug discovery process.

\section{MATERIALS AND METHODS}

\subsection{Chemicals and Reagents}

All the solvents used for the extraction of plant materials were of analytical grade and hydrochloric acid was procured from Sisco Research Laboratory (Mumbai, India). Reagents, enzymes, and positive controls such as 2,2-diphenyl-1-picrylhydrazyl (DPPH), 2,4,6-tri (2-115 pyridyl)-s-triazine, Quercetin, gallic acid, Ascorbic acid (AC), butylated hydroxytoluene, 15-Lipoxygenase (15-LOX) were purchased from SigmaAldrich (St. Louis, MO). Solvents used for high-resolution liquid chromatography-mass spectrometer (HR-LCMS) were of Spectroscopic grade obtained from SD Fine Chemicals Limited (SDFCL; Mumbai, India).

\subsection{Collection of Plant Material}

Naturally grown healthy leaf and bark samples of $M$. dactyloides were harvested and collected from the Kigga village $\left(13^{\circ} 24^{\prime} 50.8^{\prime \prime} \mathrm{N}\right.$ $\left.75^{\circ} 11^{\prime} 01.7^{\prime \prime} \mathrm{E}\right)$ located at the Western Ghats region of Karnataka, India, during September month of the monsoon season. A sample specimen of the plant was deposited at the herbarium of the Department of Studies in Botany, University of Mysore, Mysore, India. Plant materials were collected in sterile polythene bags and processed within 12 hours at the laboratory.

\subsubsection{Preparation of extracts}

The leaf and bark samples were separated, washed under running tap water to reduce undesirable materials, followed by shade drying at room temperature for 5-6 days. The dried leaf and bark samples were ground to a coarse powder using the mechanical grinder and stored at $4^{\circ} \mathrm{C}$ until further use. The leaves and bark powders were sequentially extracted using $500 \mathrm{ml}$ of solvents with increasing polarity (hexane $<$ chloroform $<$ methanol) by continuous hot percolation method using a Soxhlet apparatus (boiling point, $52^{\circ} \mathrm{C}-62^{\circ} \mathrm{C}$ ) until the solvent became colorless. The solvent extracts were concentrated in a rotary flash evaporator (G1 Heidolph, Germany) under controlled pressure and stored at $4^{\circ} \mathrm{C}$ before further analysis.

\subsection{Phytochemical Analysis}

\subsubsection{Estimation of total phenolic contents (TPC)}

Estimation of the TPC in plant extracts gives an overview of the phenolic compounds which indirectly are responsible for the bioactivity. TPC estimation was carried using the Folin-Ciocalteu reagent method according to Ainsworth and Gillespie [18]. The TPC of samples was estimated based on the standard gallic acid calibration curve with concentrations ranging from 0 to $250 \mu \mathrm{g} /$ $\mathrm{ml}$. The results were expressed as $\mathrm{mg}$ gallic acid equivalents (mg $\mathrm{GAEg}^{-1}$ ) per $100 \mathrm{~g}$ of the sample. 


\subsubsection{Estimation of total flavonoid contents (TFC)}

The TFC were estimated by the aluminum chloride method [19]. Quercetin served as a positive standard and concentrations ranging from 0 to $500 \mu \mathrm{g} / \mathrm{ml}$ were prepared, and the standard calibration curve was developed using a linear fit curve. The results were expressed as mg quercetin equivalents $\left(\mathrm{mg} \mathrm{QEg}^{-1}\right)$ per $100 \mathrm{~g}$ of the sample.

\subsection{Antioxidant Activity}

\subsubsection{DPPH radical scavenging}

Evaluation of free radical scavenging capacity of the plant extracts was carried out by DPPH method [20]. Briefly, in a 96 well microtiter plate, $10 \mu \mathrm{l}$ of different solvent extracts and $\mathrm{AC}$ were individually added to $95 \mu \mathrm{DPPH}(300 \mu \mathrm{M})$ solution in methanol. The absorbance of the samples was measured at $517 \mathrm{~nm}$ (Spectra Max 340PC Multimode plate reader) after the mixture was incubated for 30 minutes in dark at room temperature. The results were expressed as total antioxidant capacity and a dose-dependent curve was plotted to calculate the inhibitory concentration $\left(\mathrm{IC}_{50}\right)$ value and expressed as mean \pm standard deviation (SD) of three independent experiments along with the standard AC. The activity is represented as \% radical scavenging calculated with the equation:

$\%$ DPPH radical scavenging $=($ Ac-As $) /($ Ac $) \times 100$

\subsubsection{Ferric ion reducing antioxidant power (FRAP) assay}

The reducing abilities of different leaf and bark extracts were determined by the FRAP method for the electron-donating ability of antioxidants [21]. An aliquot of $30 \mu \mathrm{l}$ sample was mixed with $90 \mu \mathrm{l}$ water and $900 \mu \mathrm{l}$ FRAP reagent and incubated at $37^{\circ} \mathrm{C}$ for 30 minutes and the absorbance measures at $593 \mathrm{~nm}$ (Beckman Coulter, DU 730 Life Sciences). The calibration curve was generated using known ferrous sulfate contents ranging from 400 to $2,000 \mu \mathrm{mol}$ and the ferrous ions reduced by the sample were calculated using a regression equation. The antioxidant activity was expressed as the amount of extract required to reduce $1 \mathrm{mmol}$ of ferrous ions.

\subsubsection{5-LOX inhibition assay}

Lipoxygenase with their products plays an important role as a mediator of inflammation with series of cellular pro-inflammatory and immune-modulatory responses. Inhibition of this enzymewould regulate the progression of inflammatory response. Evaluation of LOX inhibition was studied by a spectrophotometric assay with Soybean 15-LOX measuring the loss of soybean 15-LOX activity $(5 \mu \mathrm{g})$ with $0.2 \mu \mathrm{M}$ linoleic acid (Sigma) as the substrate prepared in a solubilized state in $0.2 \mathrm{M}$ borate buffer ( $\mathrm{pH}$ 9.0) [20]. Different concentrations of plant extracts were mixed with 15-LOX enzyme and incubated for 2 minutes at room temperature. The substrate was added to the mixture and the absorbance was measured at 243 nm using a UV-Vis spectrophotometer (Beckman Coulter, DU 730 Life Sciences). Values of hydroperoxide content and lipoxygenase activity were calculated from equation,

$$
\text { Specific activity }(\mathrm{LOX})=\Delta A . V / \varepsilon .1 . c
$$

where $\Delta A$ is the value of absorbance increase per minute, $V$ is the volume of incubation mixture, $\varepsilon$ is the extinction coefficient for linoleic acid $\left(25 \times 10^{-3} \mathrm{~mol} / \mathrm{l} / \mathrm{cm}\right), 1$ is the length of the cuvette $(1$ $\mathrm{cm})$, and $\mathrm{c}$ is the concentration of enzyme in $\mathrm{mg}(0.005)$.

\subsection{High-Resolution Liquid Chromatography-Mass Spectroscopy (HR-LCMS)}

Metabolomics analysis was performed using a HR-LCMS, with UHPLC-ESI-QTOF-MS (Agilent Technologies, Santa Clara, CA). MassHunter LC/MS Data Acquisition software (version B.06.01) was used for controlling the instrument and data acquisition. MassHunter Qualitative and Quantitative Analysis software (version B.07.00) was used for data evaluation. All samples were filtered with a $0.2 \mu \mathrm{m}$ nylon membrane filter before injection.

For the chromatographic separation, Zorbax Eclipse C18, (2.1 $\times 150 \mathrm{~mm} 5$-micron) column was used with gradient solvent system, (a) water with $0.1 \%$ formic acid and (b) acetonitrile with $10 \%$ water $+0.1 \%$ formic acid (2-20 minutes-A) $95 \%$ B 5\%, 20-25 minutes (A) 5\%, (B) 95\%, and 26-30 minutes (A) $95 \%$, (B) $5 \%$ ) with $0.2 \mathrm{ml}$ minute flow rate with pressure maintained at 1,200 bar. The mass spectral data were acquired in electrospray in positive mode. The capillary voltage, source cone voltage, and extraction cone voltage were maintained at $3.25 \mathrm{kV}, 30 \mathrm{~V}$, and 4 $\mathrm{V}$, respectively, for positive mode. Nitrogen was applied as the desolvation gas at a flow rate of 9001 hours $^{-1}$. The source and desolvation temperatures were maintained at $120^{\circ} \mathrm{C}$ and $550^{\circ} \mathrm{C}$, respectively. Mass spectra were acquired over the $\mathrm{m} / \mathrm{z}$ range of $100-1,200$ at a mass resolution of 22000 FWHM (full-width half at maximum).

\subsubsection{Data processing and identification}

Raw data pre-treatment, including peak alignment, peak extraction, normalization, deconvolution, and compound identification, was carried out using Progenesis QI software (version 2.2, Waters, Milford, MA) with default settings. Untargeted data analysis with Progenesis QI exhibited 3813 and 1797 molecular features in the ESI+ mode with clean retention time-exact mass were obtained in each sample profile both in leaves and bark extract, respectively, which finally produced a matrix of features with the retention time, $m / z$, mass error, isotope similarity, and peak intensity. Each $\mathrm{m} / \mathrm{z}$ value obtained both in the leaf and bark samples was searched against the in-house databases with different parameters set for putative identification based on the score with accurate mass matching, isotope similarity, and fragmentation score along with MS/MS data also included for the identification.

\subsubsection{Building a custom in-house database}

An in-house library of different metabolites was created through a literature search of previously reported metabolites from different species of the Myristicaceae family such as M. fragrans, Myristica malabarica, Myristica beddomei [12,22-24]. The structural and spectral information of metabolites were retrieved from different online metabolites databases like Metlin (https://metlin.scripps. edu/) PubChem (https://pubchem.ncbi.nlm.nih.gov/), HMDB (https://hmdb.ca/), ChemSpider (http://www.chemspider.com/), CHEMEBI (https://www.ebi.ac.uk/chebi/) and ChEMBL (https:// 
www.ebi.ac.uk/chembl/) in ".sdf" and ". mol" file formats. These structural files were examined individually for correct information and were combined as one file in ".sdf" file format using Progenesis SDF Studio software (v1.05667/43006), for the identification of metabolites through Progenesis QI software. Similarly, other databases like bio-molecules provided by the Waters Corporation also was used for the identification.

\subsection{Statistical Analysis}

All the experiments were conducted in triplicates, and a statistically significant difference was calculated using a one-way analysis of variance at $p \leq 0.001$ followed by Tukey's post hoc test with $p \leq 0.05$ using IBM Statistical Package for the Social Sciences (version 25) software. Results were represented as mean $\pm \mathrm{SD}$

\section{RESULTS AND DISCUSSION}

\subsection{Screening and Chemical Characterization of Phytochemical Extracts}

Difficulties and challenges in conventional procedures for the identification of total chemical signatures in a complex system have been advocated for decades. The present investigation is an effort towards simplifying the critical and complex procedures using modern analytical tools to characterize and dereplicate pharmacological essentials present in the vulnerable medicinal plant $M$. dactyloides. Initially, sequential extraction of metabolites from leaves and bark of $M$. dactyloides based on the polarity of the solvents using Soxhlet apparatus was achieved using non-polar (hexane), moderately polar (chloroform), and polar (methanol) solvents. Different solvent extracts of $M$. dactyloides leaves and bark were subjected for quantitative estimation of total phenol and TFCs and antioxidant activity along with 15-LOX inhibition of individual extracts for the selection of extract with a significant amount of bioactive chemical constituents. Results of quantitative analysis for TPC and TFC indicated that methanolic extract had the highest TPC and TFC content in both leaf and bark extracts (Table 1).

\subsection{Radical Scavenging and Anti-Inflammatory Activities of Leaf and Bark Extracts of M. dactyloides}

Efforts towards finding new anti-inflammatory and antioxidant molecules always remain a prime point in pharmacological research as they are very essential to combat inflammatory and oxidative stress-induced diseases [25-30]. As the antioxidant and anti-inflammatory potential of extracts substantially correlates with their biological significance [31], in the present study the leaves and bark solvent fractions of $M$. dactyloides were evaluated for their antioxidant efficiency via anti-radical (DPPH), reducing power (Ferric Reducing Antioxidant Power) assays and anti-inflammatory efficiency through LOX inhibitory assay model. Methanolic leaf and bark extracts have shown significant antioxidant activities with an $\mathrm{IC}_{50}$ value of 1.48 and $6.88 \mu \mathrm{g} / \mathrm{ml}$ when subjected to scavenge DPPH free radicals, respectively (Table 2). They also have a significant reducing ability at 217.46 $\mathrm{mmol}\left(\mathrm{FeII}^{+}\right) / \mathrm{g}$ and $263.68 \mathrm{mmol}\left(\mathrm{FeII}^{+}\right) / \mathrm{g}$, respectively. These results highlight a strong relationship between the total phenolic/ flavonoid contents of the extracts and their antioxidant efficiency [31]. Results of anti-inflammatory potential of $M$. dactyloides indicated significant inhibitory effects on LOX when treated with methanolic leaf and bark extracts which scored lowest $\mathrm{IC}_{50}$ values of 2.4 and $10.4 \mu \mathrm{g} / \mathrm{ml}$, respectively (Table 2). Since the methanolic leaf and bark extracts of $M$. dactyloides showed promising potential in neutralizing the free radicals and inhibiting

Table 1. Total phenolic and TFC of leaves and bark extracts of Myristica dactyloides.

\begin{tabular}{cccc} 
Sl. No. & Sample & TPC $\mathbf{~ m g ~ G A E} / \mathbf{g}\left(\boldsymbol{R}^{\mathbf{2}=\mathbf{0 . 9 0 9 5})}\right.$ & TFC $\mathbf{~ m g ~} \mathbf{Q E} / \mathbf{g}\left(\boldsymbol{R}^{\mathbf{2}}=\mathbf{0 . 9 5 4 1}\right)$ \\
1. & Leaf-hexane & - & - \\
2. & Leaf-chloroform & 15.86 & 92.02 \\
3. & Leaf-methanol & 53.13 & 119.47 \\
4. & Bark-hexane & 18.92 & 43.58 \\
5. & Bark-chloroform & 13.50 & 54.88 \\
6. & Bark-methanol & 32.54 & 64.47 \\
\hline
\end{tabular}

$\mathrm{GAE} / \mathrm{g}=$ gallic acid equivalents $\left(\mathrm{mg} \mathrm{GAEg}^{-1}\right)$ per $100 \mathrm{~g}$ of the sample. $\mathrm{QE} / \mathrm{g}=$ quercetin equivalents $\left(\mathrm{mg} \mathrm{QEg}^{-1}\right)$ per $100 \mathrm{~g}$ of the sample.

Table 2. DPPH $\mathrm{IC}_{50}$ value, ferric reducing antioxidant power assay, and LOX IC $\mathrm{F}_{50}$ value of leaves and bark extracts of M. dactyloides.

\begin{tabular}{ccccc} 
SI. No. & Sample & DPPHIC $_{\mathbf{5 0}}$ value $\boldsymbol{\mu g} / \mathbf{m l}$ & FRAP $(\mathbf{m m o l}(\mathbf{F e I I}) / \mathbf{g}$ extract $)$ & LOX IC $_{\mathbf{5 0}}$ value \\
\hline 1. & Leaf-hexane & 59.47 & 111.50 & 14.5 \\
2. & Leaf-chloroform & 1.12 & 117.93 & 3.8 \\
3. & Leaf-methanol & 1.48 & 217.46 & 2.4 \\
4. & Bark-hexane & 31.93 & 126.51 & 15.1 \\
5. & Bark-chloroform & 11.29 & 223.86 & 13.6 \\
6. & Bark-methanol & 6.88 & 263.68 & 10.4 \\
7. & AC & 1.61 & 350.76 & 9 \\
\hline
\end{tabular}

$\mathrm{IC}_{50}=$ inhibitory concentration at $50 \%$ sample. 
LOX, these extracts were further subjected to metabolite profiling to catalog their important chemical constituents which may have potent bioactivities [32].

\subsection{High-Resolution Liquid Chromatography Mass Spectrometry (HR-LC-ESI-MS/MS) Analysis of Bioactive Extract}

Conventional methods of characterization of bioactive phytoconstituents involve series of steps that include extraction, evaluation, chromatographic separation, and spectroscopic characterization. However, due to the unavailability of suitable phytochemical standards, most of the researchers end up characterizing few known phytochemicals despite extensive effort and time. Hence unveiling the complex chemistry of bioactive crude extracts using high throughput and high-resolution techniques is a key to pinpoint the pharmaceutically potent bioactives and simplify the efforts to understand its action on the target. Among genus Myristica, there is overwhelming research on understanding the chemistry of Myristica fragrans, common name "nutmug," due to its innumerable medicinal and bioactive applications [12]. However, in spite of its usage as a replacement constituent for $M$. fragrans, the efforts towards understanding the chemistry of $M$. dactyloides have remained considerably low. Hence in the present study, HR-LC-ESI-MS/MS was used in order to characterize the chemical composition of methanolic crude extracts of leaves and bark from $M$. dactyloides. Untargeted data analysis with Progenesis QI exhibited 3,093 and 1,797 molecular features in the ESI+ mode with clean retention time-exact mass in the sample profile of leaves and bark extract, respectively. For the identification of compounds, an in-house database of previously reported metabolites from different species of the Myristicaceae family such as $M$. fragrans, $M$. malabarica, $M$. beddomei $[12,22-24]$ used with a mass accuracy of $10 \mathrm{ppm}$. Similarly, other databases like bio-molecules provided by the Waters Corporation also was used for the identification.

The representative base peak chromatogram of $M$. dactyloides leaf and bark extracts is depicted in Figure 1A and B and the phytochemical identification data is presented in Table 3, which summarizes the tentative compounds characterized from these extracts including their retention time, experimental $\mathrm{m} / \mathrm{z}$, mass, proposed metabolites, molecular formula, and reported activity. These compounds mainly belong to lignans, neolignans, phenylpropanoids, diarylnonanoid, flavonoids, and others.

The LC chromatograms of both leaves and bark showed a varied concentration of metabolites present in each extract, with leaves showing higher metabolite content compared to bark due to the production of metabolites based on light-dependent pathways and the abundance profile of representative compounds (Fig. 2) both in leaf and bark also supports the leaves showing higher metabolite content. Mass Fragmentation trace of representative compounds like Malabaricone C, Malabaricone B, Guaiacin, Myricanone, and Epicatechin along with their and structures are given in Figure 3. In addition, there are considerable number of metabolites present both in leaves and bark extract as only a few metabolites have been focused in the present study.
The HR-LC-ESI-MS/MS data highlighted the increased concentration of lignans and neolignane derivatives in the leaf and bark extracts of $M$. dactyloides. Lignans and neolignans are the derivatives of phenylpropanoids generated through oxidative coupling and are among the major group of plant secondary metabolites found in the genus Myristica [12,33]. The peak at $m / z 390$ was proposed to be Myrifralignan A, a compound identified in $M$. fragrans and reported to have nitric oxide radical scavenging activity $[12,34]$. A peak at $m / z 360$ was identified as Austrobailignan 7 (A7) the existence of which was also reported in $M$. fragrans, Urbanodendron verrucosum, and several other plant systems $[35,36]$. However, research efforts in unveiling the biological significance of this compound remained inconclusive compared to its analogs such as Austrobailignan 1, Austrobailignan 3, Austrobailignan 5, and Austrobailignan 6 which were extensively evaluated for their anti-inflammatory, antioxidant, anti-cancer, and anti-wrinkling activities [3740]. Peak at 295, with the mass of 330.1467 was proposed as Fragransol B which was only identified in M. fragrans and its biological significance has remained largely unknown. Peak at $m / z 309$ is identified as Machilin A, previously reported in the members of genus Machilus and Myristica and is a well-known inhibitor of cytochrome P450 1A and 2B6 [41,42].

Similarly, several other lignans and neolignans like Argenteane, (peak at $m / z$ 619), Nectandrin A (peak at $m / z$ 376), Myristicanol B (peak at $m / z$ 405), Myrifralignan E (peak at $m / z$ 383), Fragransin D1 (peak at $m / z$ 406), Sesamin (peak at $m / z$ 337), Guaiacin (peak at $m / z$ 329 ) detected in the methanolic extracts of leaf and bark sample of $M$. dactyloides in the present study strongly advocate the potential of these groups of compounds for biological activities [12,34,4348]. Monotropein an iridoid glycoside tentatively annotated for the molecular ion at $m / z 391.1238(\mathrm{M}+\mathrm{H})$ previously reported from the Morinda officinalis with well-established Antinociceptive and anti-inflammatory potential $[49,50]$. In addition, the present study also revealed the pharmacological richness in $M$. dactyloides wherein 25 bioactive chemical compounds other than lignans and neolignans were identified. These include alcoholic sugars, flavonoids, and steroids like Myoinositol, Methylisoeugenol, Monotropein, Parakmerin A, Eugenol, Anthriscinol, Syringic acid, Fragransol C, $(+)$-Epicatechin, Elemicin, Eugenol, Malabaricone D, (+)-Myristinin A, (+)-Myristinin D, 1-(2,6-Dihydroxyphenyl)9-(4-Hydroxy-3-Methoxyphenyl), Dihydroguaiaretic acid, 4-Terpineol, Malabaricone C (Mal C), Malabaricone B (Mal B), Myricanone, Dodecanoylphloroglucinol, Safrole, Isoeugenol, and Daucosterol.

Myoinositol, Malabaricone B, Malabaricone C, Malabaricone D, and 1-(2,6-dihydroxyphenyl)-9-(4-hydroxy-3-methoxyphenyl) nonan-1-one which have been previously reported from the $M$. dactyloides have also been identified in the present study confirming their presence in the plant $[13,14]$.

In addition to the above phytochemical constituents, the presence of compounds Mal C and Mal B, which are present in most of the members of genus Myristica potentially proves its consideration in developing a chemo-taxonomical library for the identification of this genus. Mal $\mathrm{C}$ is one among the extensively explored 

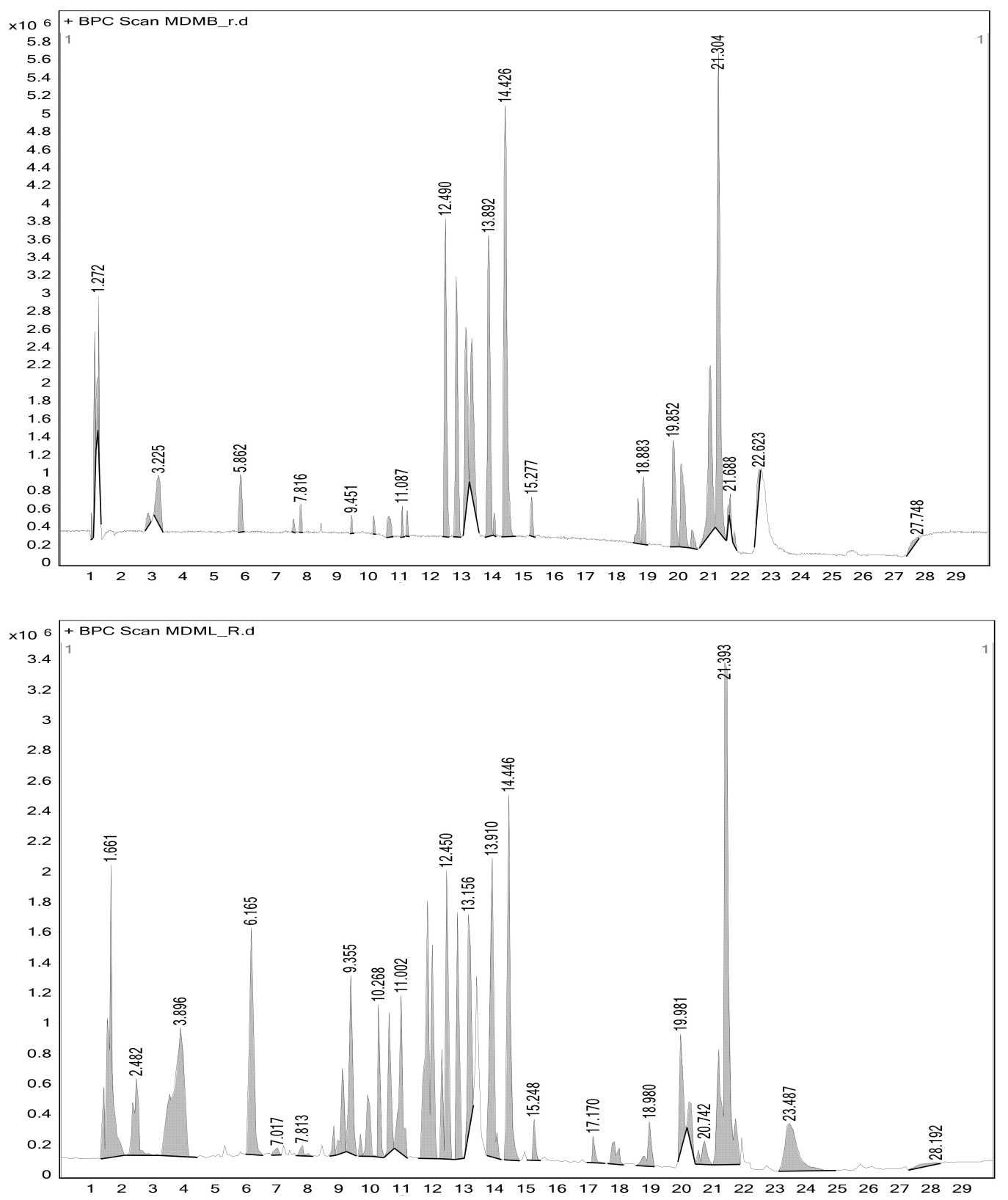

Figure 1. LC chromatograms methanol extracts of (a) Bark and (b) Leaf of Myristica dactyloides.

chemical content predominantly present in genus Myristica, known for its possible therapeutic potential for treating cancer and inflammatory disorders [51,52], Alzheimer's disease [53], and infectious diseases [54]. The present study also highlights the importance of exploring the bioactive potential of Mal B which is underutilized compared to Mal C. The presence of Mal C and Mal B in $M$. dactyloides may be responsible for the antioxidant and anti-inflammatory efficiency in the extracts recorded earlier in preliminary in vitro investigation.

The present investigation also added prominent chemical signatures like Monotropein Malabaricone B, Malabaricone
C, Fragransol B, Guaiacin, Myricanone, and Epicatechin to the phytochemical catalog of $M$. dactyloides. Though the components like Malabaricone C, Monotropein have been studied extensively by researchers worldwide, the other chemical constitutes cataloged in this study are more promising for pharmacological industries facing challenges in the discovery of synthetic drugs which is known to be expensive and risky in terms of capital investment and side effects. The unexplored phytochemicals cataloged from $M$. dactyloides for their bioactive potentials represent novel natural interventions towards finding a solution for the industrial challenges. 
Table 3. List of major chemical constituents identified from methanolic extracts of leaves and bark of Myristica dactyloides using HR-LCESIMS/MS.

\begin{tabular}{|c|c|c|c|c|c|c|c|c|}
\hline $\begin{array}{l}\text { Retention } \\
\text { time } \\
\text { (minute) }\end{array}$ & $m / z$ & $\begin{array}{l}\text { Neutral } \\
\text { mass }\end{array}$ & Proposed metabolites & Formula & Adducts & $\begin{array}{l}\text { Mass } \\
\text { error } \\
(\mathbf{p p m})\end{array}$ & Activity & Reference \\
\hline \multicolumn{9}{|c|}{ Lignans and neolignans } \\
\hline 1.2717 & 390.1883 & 372.4116 & Myrifralignan A Neolignan & $\mathrm{C}_{21} \mathrm{H}_{24} \mathrm{O}_{6}$ & $\mathrm{M}+\mathrm{NH}_{4}$ & -7.5 & \multirow[t]{2}{*}{ Anti-inflammatory } & {$[12,34]$} \\
\hline 2.0896 & 279.1354 & 296.1412 & Parakmerin A (Lignan) & $\mathrm{C}_{19} \mathrm{H}_{20} \mathrm{O}_{3}$ & $\begin{array}{c}\mathrm{M}+\mathrm{H}- \\
\mathrm{H}_{2} \mathrm{O}\end{array}$ & -8.3 & & {$[55]$} \\
\hline 5.6954 & 209.0825 & 208.0735 & $\begin{array}{l}\text { Anthriscinol (Lignan } \\
\text { phenylpropanoid) }\end{array}$ & $\mathrm{C}_{11} \mathrm{H}_{12} \mathrm{O}_{4}$ & $\mathrm{M}+\mathrm{H}$ & 8.2 & \multirow[t]{4}{*}{$\begin{array}{c}\text { CC chemokine receptor } 3 \\
\text { antagonist }\end{array}$} & {$[56,57]$} \\
\hline 6.2463 & 321.1506 & 356.1623 & Fragransol C(Neolignan) & $\mathrm{C}_{21} \mathrm{H}_{24} \mathrm{O}_{5}$ & $\begin{array}{l}\mathrm{M}+\mathrm{H}- \\
2 \mathrm{H}_{2} \mathrm{O}\end{array}$ & 6.03 & & {$[35,58]$} \\
\hline 7.8989 & 360.1792 & 342.1467 & (+)-Machilin F (Lignan) & $\mathrm{C}_{20} \mathrm{H}_{22} \mathrm{O}_{5}$ & $\mathrm{M}+\mathrm{NH}_{4}$ & -3.84 & & {$[59]$} \\
\hline 9.201 & 295.1317 & 330.1467 & Fragransol B (Lignan) & $\mathrm{C}_{19} \mathrm{H}_{22} \mathrm{O}_{5}$ & $\begin{array}{l}\mathrm{M}+\mathrm{H}- \\
2 \mathrm{H}_{2} \mathrm{O}\end{array}$ & -3.42 & & {$[35]$} \\
\hline 10.3028 & 309.1470 & 326.1518 & Machilin A (Lignan) & $\mathrm{C}_{20} \mathrm{H}_{22} \mathrm{O}_{4}$ & $\begin{array}{c}\mathrm{M}+\mathrm{H}- \\
\mathrm{H}_{2} \mathrm{O}\end{array}$ & -4.43 & $\begin{array}{c}\text { Inhibits tumor growth, } \\
\text { stimulates osteoblast } \\
\text { differentiation }\end{array}$ & {$[59,60]$} \\
\hline 13.1406 & 619.3038 & 654.3192 & Argenteane (Dilignan) & $\mathrm{C}_{40} \mathrm{H}_{46} \mathrm{O}_{8}$ & $\begin{array}{l}\mathrm{M}+\mathrm{H}- \\
2 \mathrm{H}_{2} \mathrm{O}\end{array}$ & -2.39 & Antioxidant & {$[43]$} \\
\hline 13.992 & 376.2147 & 358.1780 & Nectandrin A (Lignan) & $\mathrm{C}_{21} \mathrm{H}_{26} \mathrm{O}_{5}$ & $\mathrm{M}+\mathrm{NH}_{4}$ & 8.17 & $\begin{array}{l}\text { AMP-activated protein kinase } \\
\text { (AMPK) activators }\end{array}$ & {$[45,61]$} \\
\hline 14.8768 & 348.2141 & 330.18319 & $\begin{array}{c}\text { Dihydroguaiaretic acid (Lignans, } \\
\text { neolignans) }\end{array}$ & $\mathrm{C}_{20} \mathrm{H}_{26} \mathrm{O}_{4}$ & $\mathrm{M}+\mathrm{NH}_{4}$ & -8.50 & Antioxidant & {$[62,63]$} \\
\hline 16.8967 & 405.1947 & 404.1835 & Myristicanol B (Lignan) & $\mathrm{C}_{22} \mathrm{H}_{28} \mathrm{O}_{7}$ & $\mathrm{M}+\mathrm{H}$ & 9.79 & Inhibit lipid peroxidation & {$[46,58]$} \\
\hline 17.264 & 383.1499 & 418.1627 & Myrifralignan E (Neolignans) & $\mathrm{C}_{22} \mathrm{H}_{26} \mathrm{O}_{8}$ & $\begin{array}{l}\mathrm{M}+\mathrm{H}- \\
2 \mathrm{H}_{2} \mathrm{O}\end{array}$ & 2.45 & Inhibit nitric oxide production & {$[12,34]$} \\
\hline 17.264 & 406.2260 & 388.1885 & Fragransin D1 (Lignan) & $\mathrm{C}_{22} \mathrm{H}_{28} \mathrm{O}_{6}$ & $\mathrm{M}+\mathrm{NH}_{4}$ & 9.27 & & {$[35]$} \\
\hline 17.3474 & 337.1091 & 354.1103 & Sesamin (Lignan) & $\mathrm{C}_{20} \mathrm{H}_{18} \mathrm{O}_{6}$ & $\begin{array}{c}\mathrm{M}+\mathrm{H}- \\
\mathrm{H}_{2} \mathrm{O}\end{array}$ & 5.83 & $\begin{array}{l}\text { Antioxidant, anti-inflammatory, } \\
\text { anticancer }\end{array}$ & {$[47]$} \\
\hline 19.5844 & 365.1362 & 342.1467 & Austrobailignan 7 (Lignan) & $\mathrm{C}_{20} \mathrm{H}_{22} \mathrm{O}_{5}$ & $\mathrm{M}+\mathrm{Na}$ & 0.91 & & {$[35]$} \\
\hline 21.8714 & 329.1752 & 328.1674 & $\begin{array}{c}\text { Guaiacin (Saponin, Lignans, } \\
\text { neolignans) }\end{array}$ & $\mathrm{C}_{20} \mathrm{H}_{24} \mathrm{O}_{4}$ & $\mathrm{M}+\mathrm{H}$ & 1.43 & $\begin{array}{l}\text { NeuroprotectiveAnti- } \\
\text { inflammatory }\end{array}$ & {$[64,65]$} \\
\hline \multicolumn{9}{|c|}{ Phenylpropanoids } \\
\hline 1.255 & 201.0902 & 178.1010 & $\begin{array}{l}\text { Methylisoeugenol } \\
\text { (Phenylpropanoid) }\end{array}$ & $\mathrm{C}_{11} \mathrm{H}_{14} \mathrm{O}_{2}$ & $\mathrm{M}+\mathrm{Na}$ & 9.2 & $\begin{array}{l}\text { Antinociceptive \& anti- } \\
\text { inflammatory }\end{array}$ & {$[12,66]$} \\
\hline 3.8925 & 165.0919 & 164.0837 & Eugenol (Phenylpropanoid) & $\mathrm{C}_{10} \mathrm{H}_{12} \mathrm{O}_{2}$ & $\mathrm{M}+\mathrm{H}$ & 5.6 & Anti-inflammatory & {$[67]$} \\
\hline 7.8822 & 226.1422 & 208.1099 & Elemicin (Phenylpropanoid) & $\mathrm{C}_{12} \mathrm{H}_{16} \mathrm{O}_{3}$ & $\mathrm{M}+\mathrm{NH}_{4}$ & -7.07 & & {$[12,68]$} \\
\hline 7.9323 & 182.1188 & 164.0837 & Eugenol & $\mathrm{C}_{10} \mathrm{H}_{12} \mathrm{O}_{2}$ & $\mathrm{M}+\mathrm{NH}_{4}$ & 8.05 & Anti-inflammatory & {$[67]$} \\
\hline 21.6878 & 180.1003 & 162.0680 & Safrole Phenylpropanoids & $\mathrm{C}_{10} \mathrm{H}_{10} \mathrm{O}_{2}$ & $\mathrm{M}+\mathrm{NH}_{4}$ & -9.75 & Tyrosinase inhibitory & {$[69]$} \\
\hline 28.8827 & 147.0816 & 164.0837 & Isoeugenol (Terpenoid) & $\mathrm{C}_{10} \mathrm{H}_{12} \mathrm{O}_{2}$ & $\begin{array}{c}\mathrm{M}+\mathrm{H}- \\
\mathrm{H}_{2} \mathrm{O}\end{array}$ & 7.23 & Antioxidant & {$[22]$} \\
\hline \multicolumn{9}{|c|}{ Diarylnonanoid, diarylalkanone, and diarylheptanoid } \\
\hline 8.4832 & 353.1743 & 370.1780 & Malabaricone D (Diarylnonanoid) & $\mathrm{C}_{22} \mathrm{H}_{26} \mathrm{O}_{5}$ & $\begin{array}{c}\mathrm{M}+\mathrm{H}- \\
\mathrm{H}_{2} \mathrm{O}\end{array}$ & -1.02 & & {$[70]$} \\
\hline 13.3076 & 395.1810 & 372.1936 & $\begin{array}{l}\text { 1-(2,6-Dihydroxyphenyl)-9-(4- } \\
\text { Hydroxy-3-Methoxyphenyl) } \\
\text { Nonan-1-One (Diarylalkanone) }\end{array}$ & $\mathrm{C}_{22} \mathrm{H}_{28} \mathrm{O}_{5}$ & $\mathrm{M}+\mathrm{Na}$ & -5.02 & Antiproliferative & {$[8,24]$} \\
\hline 17.0637 & 359.1885 & 358.1812 & Malabaricone C (Diarylnonanoid) & $\mathrm{C}_{21} \mathrm{H}_{26} \mathrm{O}_{5}$ & $\mathrm{M}+\mathrm{H}$ & 9.01 & Anti-inflammatory & {$[70,71]$} \\
\hline 17.0804 & 357.1714 & 356.1623 & Myricanone (Diarylheptanoid) & $\mathrm{C}_{21} \mathrm{H}_{24} \mathrm{O}_{5}$ & $\mathrm{M}+\mathrm{H}$ & 5.07 & Anticancer & {$[72]$} \\
\hline 18.4826 & 343.1933 & 342.1831 & Malabaricone B (Diarylnonanoid) & $\mathrm{C}_{21} \mathrm{H}_{26} \mathrm{O}_{4}$ & $\mathrm{M}+\mathrm{H}$ & 8.54 & $\begin{array}{l}\text { Antimicrobial, anti- } \\
\text { inflammatory }\end{array}$ & {$[70,73]$} \\
\hline 21.6377 & 309.2067 & 308.1987 & Dodecanoylphloroglucinol & $\mathrm{C}_{18} \mathrm{H}_{28} \mathrm{O}_{4}$ & $\mathrm{M}+\mathrm{H}$ & 2.18 & $\begin{array}{c}\text { Antituberculosis \& antiviral } \\
\text { activity }\end{array}$ & {$[74]$} \\
\hline
\end{tabular}




\begin{tabular}{|c|c|c|c|c|c|c|c|c|}
\hline $\begin{array}{l}\text { Retention } \\
\text { time } \\
\text { (minute) }\end{array}$ & $m / z$ & $\begin{array}{l}\text { Neutral } \\
\text { mass }\end{array}$ & Proposed metabolites & Formula & Adducts & $\begin{array}{l}\text { Mass } \\
\text { error } \\
(p p m)\end{array}$ & Activity & Reference \\
\hline \multicolumn{9}{|c|}{ Flavonoids and others } \\
\hline 7.7988 & 291.0891 & 290.0818 & $(+)$-Epicatechin (Flavanol) & $\mathrm{C}_{15} \mathrm{H}_{14} \mathrm{O}_{6}$ & $\mathrm{M}+\mathrm{H}$ & 9.6 & Antioxidant, anti-inflammatory & {$[75]$} \\
\hline 9.5516 & 571.2665 & 548.2774 & $(+)$-Myristinin A (Flavan) & $\mathrm{C}_{33} \mathrm{H}_{40} \mathrm{O}_{7}$ & $\mathrm{M}+\mathrm{Na}$ & -0.18 & $\begin{array}{l}\text { COX-2 inhibitors and } \\
\text { antifungal agent }\end{array}$ & {$[76]$} \\
\hline 10.837 & 565.2573 & 582.2617 & (+)-Myristinin D (Flavan) & $\mathrm{C}_{36} \mathrm{H}_{38} \mathrm{O}_{7}$ & $\begin{array}{c}\mathrm{M}+\mathrm{H}- \\
\mathrm{H}_{2} \mathrm{O}\end{array}$ & -1.90 & $\begin{array}{l}\text { COX-2 inhibitors and } \\
\text { antifungal agent }\end{array}$ & {$[76]$} \\
\hline 1.2049 & 203.0545 & 180.0653 & Myo-inositol (Carbocyclic sugar) & $\mathrm{C}_{7} \mathrm{H}_{8} \mathrm{~N}_{4} \mathrm{O}_{2}$ & $\mathrm{M}+\mathrm{Na}$ & 3.4 & Anti-inflammatory & {$[13,77]$} \\
\hline 1.8225 & 391.1238 & 390.1162 & Monotropein (Iridoid glycoside) & $\mathrm{C}_{16} \mathrm{H}_{22} \mathrm{O}_{11}$ & $\mathrm{M}+\mathrm{H}$ & 1.02 & $\begin{array}{l}\text { Antinociceptive, anti- } \\
\text { inflammatory }\end{array}$ & {$[49,50]$} \\
\hline 5.7956 & 199.0600 & 198.0528 & Syringic acid (Phenolic) & $\mathrm{C}_{9} \mathrm{H}_{10} \mathrm{O}_{5}$ & $\mathrm{M}+\mathrm{H}$ & -0.068 & $\begin{array}{l}\text { Antioxidant, anti-microbial, } \\
\text { anti-inflammation, anti-cancer, } \\
\text { anti-diabetic }\end{array}$ & {$[78]$} \\
\hline 15.1272 & 172.1706 & 154.1357 & 4-Terpineol (Isoprenoids) & $\mathrm{C}_{10} \mathrm{H}_{18} \mathrm{O}$ & $\mathrm{M}+\mathrm{NH} 4$ & 6.82 & $\begin{array}{c}\text { Anticancer, antioxidant, anti- } \\
\text { inflammatory }\end{array}$ & {$[79,80]$} \\
\hline 27.18 & 541.4288 & 576.4389 & Daucosterol (Terpenoid) & $\mathrm{C}_{35} \mathrm{H}_{60} \mathrm{O}_{6}$ & $\begin{array}{l}\mathrm{M}+\mathrm{H}- \\
2 \mathrm{H}_{2} \mathrm{O}\end{array}$ & 6.36 & Immunoregulatory, anti-cancer & {$[81,82]$} \\
\hline
\end{tabular}

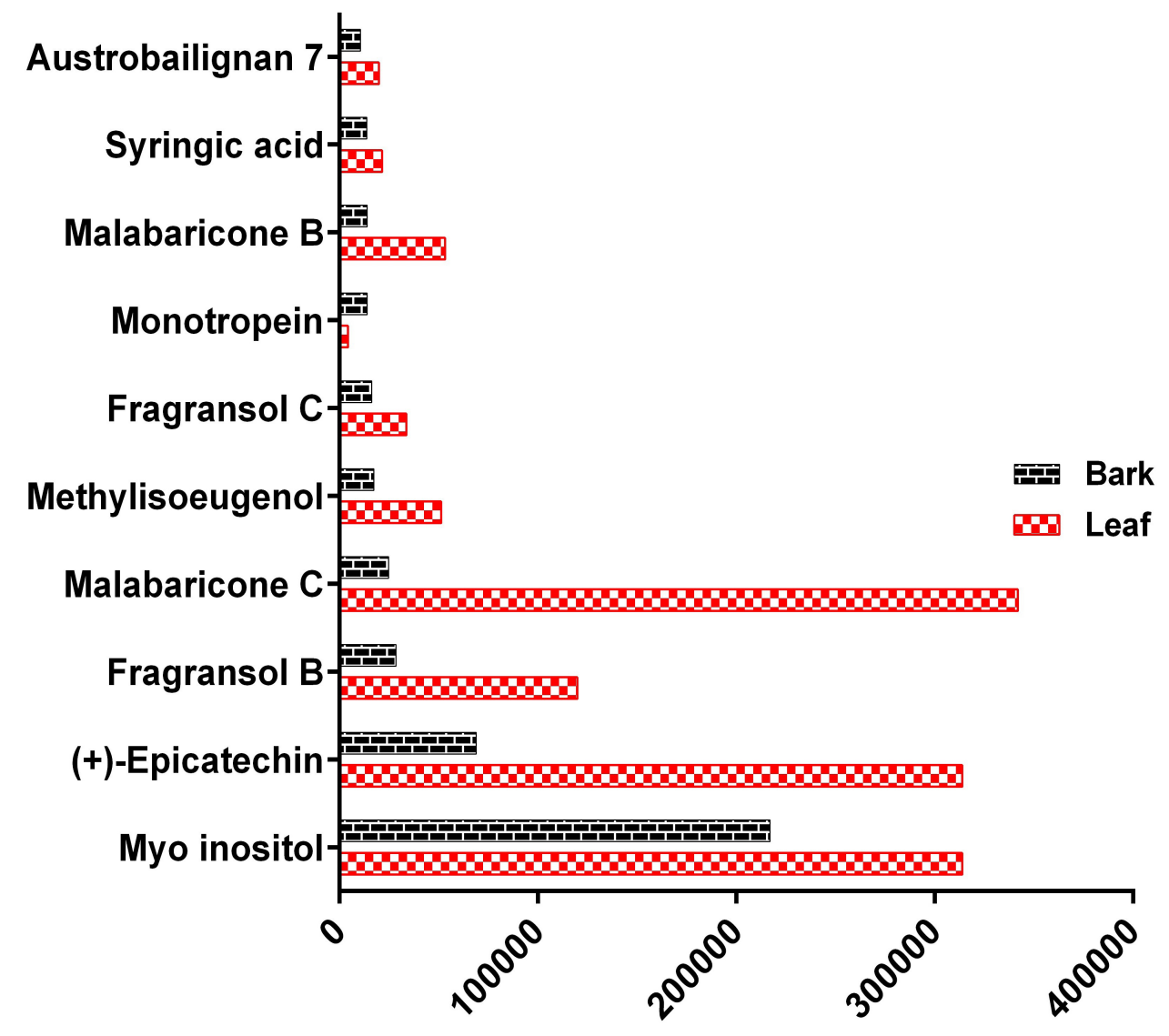

Figure 2. Abundance profile of representative compounds from leaf and bark extract. 

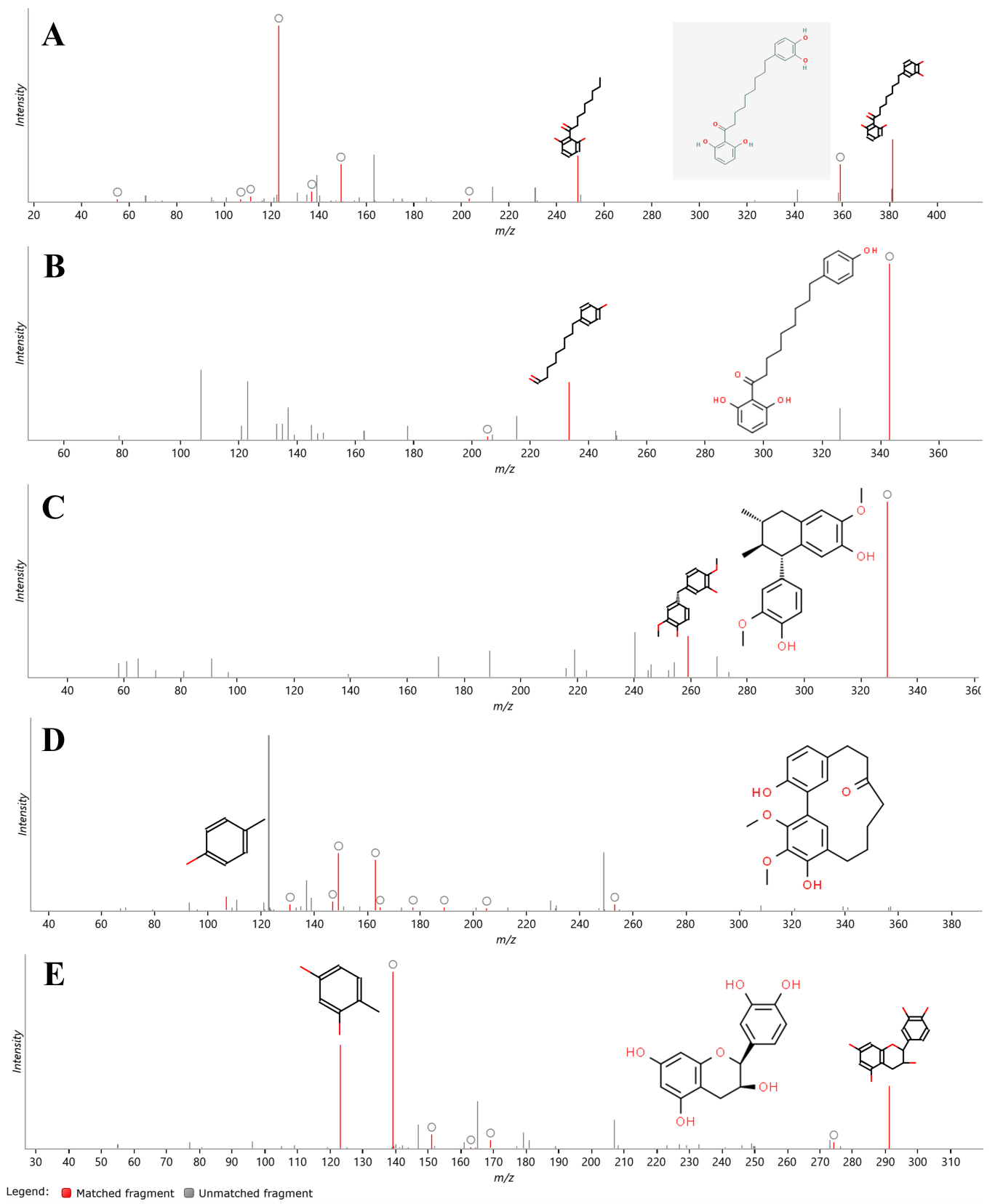

Figure3. Mass fragmentation trace and structures of (A). Malabaricone (C, B). Malabaricone (B, C). Guaiacin, (D). Myricanone and (E) Epicatechin.

\section{CONCLUSION}

The present study is a first report to the best of authors' knowledge, on cataloging the chemicals constituents in leaves and bark methanolic extracts of $M$. dactyloides, and indicates chemical and bioactive resemblance between $M$. dactyloides and $M$. fragrans (Table 3). This evidently supports the current practice of using $M$. dactyloides as a viable alternative in pharmaceutical formulations of $M$. fragrans. The study also highlights the potential of modern analytical tools in cataloging chemical constituents within a genus of medicinally important plants, which may certainly aid in the development of a chemo-taxonomical database to authenticate and identify the plant species. The present investigation strongly advocates the importance of constructing a medicinal plant species-based chemical library which can be accessed by researchers for developing species-specific chemo-taxonomical tools in the future. This will in turn cut down the time taken for the characterization of bioactive compounds from natural resources.

\section{AUTHORS' CONTRIBUTIONS}

All the authors have made substantive intellectual contributions to the content of this manuscript in the following areas: Concept and design - KMM and KRK, Data acquisition and analysis-KMM, and BRN, Drafting manuscript-KMM, SCR, BRN, and KRK. Critical revision of Manuscript-SNB, KKSK, and SS, Statistical analysis - KMM and BRN, and Supervision and Final approvalKRK. 


\section{ACKNOWLEDGMENTS}

The author was financially supported through the UGC: National Fellowship for Higher Education (NFHE) for this study. The authors are grateful to Dr. Paul N Goulding, Senior Business Development Manager, Asia, Africa, and Australasia for providing the Progenesis QI and valuable suggestions for this work. The authors are thankful to the Sophisticated Analytical Instrument Facility (SAIF), IIT Bombay instrumentation facility. The authors are also grateful to the Institution of Excellence (IOE), University of Mysore, for the instrumentation facility.

\section{CONFLICT OF INTEREST}

The authors have declared no conflict of interest.

\section{ETHICAL APPROVALS}

This study does not involve experiments on animals or human subjects.

\section{REFERENCES}

1. Brusotti G, Cesari I, Dentamaro A, Caccialanza G, Massolini G. Isolation and characterization of bioactive compounds from plant resources: the role of analysis in the ethnopharmacological approach. J Pharm Biomed Anal 2014;87:218-28; doi:10.1016/j.jpba.2013.03.007

2. Liu Q, Jiao Z, Liu Y, Li Z, Shi X, Wang W, et al. Chemical profiling of San-Huang decoction by UPLC-ESI-Q-TOF-MS. J Pharm Biomed Anal 2016;131:20-32; doi:10.1016/j.jpba.2016.07.036

3. Farag MA, Maamoun AA, Ehrlich A, Fahmy S, Wesjohann LA. Assessment of sensory metabolites distribution in 3 cactus Opuntia ficus-indica fruit cultivars using UV fingerprinting and GC/MS profiling techniques. LWT- Food Sci Technol 2017;80:145-54.

4. Kind T, Tsugawa H, Cajka T, Ma Y, Lai Z, Mehta SS, et al. Identification of small molecules using accurate mass MS/MS search. Mass Spectrom Rev 2018;37:513-32; doi:10.1002/mas.21535

5. Noumi E, Snoussi M, Anouar EH, Alreshidi M, Veettil VN, Elkahoui $\mathrm{S}$, et al. HR-LCMS-based metabolite profiling, antioxidant, and anticancer properties of Teucrium polium 1. Methanolic extract: computational and in vitro study. Antioxidants 2020;9:1-23; doi:10.3390/antiox9111089

6. Tsugawa H. Advances in computational metabolomics and databases deepen the understanding of metabolisms. Curr Opin Biotechnol 2018;54:10-7; doi:10.1016/j.copbio.2018.01.008

7. Tabudravu JN, Pellissier L, Smith AJ, Subko K, Autréau C, Feussner K, et al. LC-HRMS-Database screening metrics for rapid prioritization of samples to accelerate the discovery of structurally new natural products. J Nat Prod 2019;82:211-20; doi:10.1021/acs. jnatprod.8b00575

8. Herath HMTB, Priyadarshani AMA. Two lignans and an aryl alkanone from Myristica dactyloides. Phytochemistry 1996;42:1439-42; doi:10.1016/0031-9422(96)00113-6

9. Christenhusz MJM, Byng JW. The number of known plants species in the world and its annual increase. Phytotaxa 2016;261:201; doi:10.11646/phytotaxa.261.3.1

10. Haridasan D, Ravikumar K, Saha K, Ved D. Myristica dactyloides the IUCN red list of threatened species. 2015;8235; doi:10.2305/ IUCN.UK.2015-2.RLTS.T33526A50131225.en. International Union for Conservation of Nature Red List of Threatened Species website. Available via https://www.iucnredlist.org/species/33526/50131225

11. Jayaweera DMA. Medicinal plants used in Ceylon. Part. 3 . National Science Council of Sri Lanka, Colombo, Sri Lanka, p 161, 1982.

12. Abourashed EA, El-Alfy AT. Chemical diversity and pharmacological significance of the secondary metabolites of nutmeg (Myristica fragrans Houtt.). Phytochem Rev 2016; 15:1035-56; doi:10.1007/ s11101-016-9469-x

13. Tillekeratne LMV, Jayamanne DT, Weerasooria KDV. Chemical constituents of Myristica dactyloides. J Natn Sci Coun 1981;9:251-3.

14. Wijesekera TP, Babel M, Nair NF, Cooray ER, Jansz S. Wimalasena, ceylon, acylresorcinols from seed kernels of Myristica dactyloides. Phytochemistry 1987;26:3369-71.

15. Herath HMTB, Priyadarshani AMA, Jamie J. Dactyloidin, a new diaryl nonanoid from Myristica Dactyloides, Nat Prod Lett 1998; 12;91-5; https://doi.org/10.1080/10575639808048275

16. Kumar NS, Herath HMTB, Karunaratne V. Arylalkanones from Myristica dactyloides, Phytochemistry 1988;27:465-68.

17. Herath HMTB, Priyadarshani AMA, Jamie J. Lignans from Myrstica dactyloides. Phytochemistry 1997;44:699-703.

18. Ainsworth EA, Gillespie KM. Estimation of total phenolic content and other oxidation substrates in plant tissues using folin-ciocalteu reagent. Nat Protoc 2007;2:875-7; doi:10.1038/nprot.2007.102

19. Zhang L, Ravipati AS, Koyyalamudi SR, Jeong SC, Reddy N, Smith $\mathrm{PT}$, et al. Antioxidant and anti-inflammatory activities of selected medicinal plants containing phenolic and flavonoid compounds. J Agric Food Chem 2011;59:12361-7.

20. Sekhar S, Kk S, Niranjana SR, Prakash HS. In vitro antioxidant activity, lipoxygenase, cyclooxygenase-2 inhibition and DNA protection properties of Memecylon species. Int J Pharm Pharm Sci 2013;5:257-62.

21. Nagarani G, Abirami A, Siddhuraju P. A comparative study on antioxidant potentials, inhibitory activities against key enzymes related to metabolic syndrome, and anti-inflammatory activity of leaf extract from different Momordica species. Food Sci Hum Wellness 2014;3:36-46; doi:10.1016/j.fshw.2014.02.003

22. John Zachariah BKT, Leela NK, Maya KM, Rema J, Mathew PA, Vipin TM. Chemical composition of leaf oils of Myristica beddomei (King), Myristica fragrans (Houtt.) and Myristica malabarica (Lamk.). J Spices Aromat Crop 2008;17:10-5. Available via https:// core.ac.uk/download/pdf/236023673.pdf

23. Asgarpanah J, Kazemivash N. Phytochemistry and pharmacologic properties of Myristica fragrans Hoyutt.: a review. Afr J Biotechnol 2012;11:12787-93; doi:10.5897/AJB12.1043

24. Pandey R, Mahar R, Hasanain M, Shukla SK, Sarkar J, Rameshkumar $\mathrm{KB}$, et al. Rapid screening and quantitative determination of bioactive compounds from fruit extracts of Myristica species and their in vitro antiproliferative activity. Food Chem 2016;211:483-93; doi:10.1016/j. foodchem.2016.05.065

25. Mackay CR. Moving targets: cell migration inhibitors as new antiinflammatory therapies. Nat Immunol 2008;9:988-98; doi:10.1038/ ni.f. 210

26. Kizhakekuttu TJ, Widlansky ME. Natural antioxidants and hypertension: promise and challenges. Cardiovasc Ther 2010;28:e20-32.

27. Zatalia SR, Sanusi H. The role of antioxidants in the pathophysiology, complications, and management of diabetes mellitus. Acta Med Indones 2013; 45:141-7.

28. Matés JM, Segura JA, Alonso FJ, Márquez J. Natural antioxidants: therapeutic prospects for cancer and neurological diseases. Mini Rev Med Chem 2009;9:1202-14.

29. Sahgal G, Ramanathan S, Sasidharan S, Mordi MN, Ismail S, Mansor SM. In vitro antioxidant and xanthine oxidase inhibitory activities of methanolic Swietenia mahagoni seed extracts. Molecules 2009;14:4476-85; doi:10.3390/molecules 14114476

30. Pohl F, Lin PKT. The potential use of plant natural products and plant extracts with antioxidant properties for the prevention/treatment of neurodegenerative diseases: in vitro, in vivo and clinical trials Molecules 2018;23:3283.

31. Ravipati AS, Zhang L, Koyyalamudi SR, Jeong SC, Reddy N, Bartlett $\mathrm{J}$, et al. Antioxidant and anti-inflammatory activities of selected Chinese medicinal plants and their relation with antioxidant content. BMC Complement Altern Med 2012;12:5-10; doi:10.1186/14726882-12-173 
32. Nanda BL, Nataraju A, Rajesh R, Rangappa KS, Shekar MA, Vishwanath BS. PLA2 mediated arachidonate free radicals: PLA2 inhibition and neutralization of free radicals by anti-oxidants-a new role as anti-inflammatory molecule. Curr Top Med Chem 2007;7: 765-77.

33. Zálešák F, Bon DJYD, Pospíšil J. Lignans and Neolignans: Plant secondary metabolites as a reservoir of biologically active substances. Pharmacol Res 2019;146:104284; doi:10.1016/j.phrs.2019.104284

34. Cao GY, Xu W, Yang XW, Gonzalez FJ, Li F. New neolignans from the seeds of Myristica fragrans that inhibit nitric oxide production. Food Chem 2015;173:231-7.

35. Hada S, Hattori M, Tezuka Y, Kikuchi T, Namba T. New neolignans and lignans from the aril of Myristica fragrans. Phytochemistry 1988;27:563-8; doi:10.1016/0031-9422(88)83142-X

36. Dias AF, Giesbrecht AM, Gottlieb OR. Neolignans from Urbanodendron verrucosum. Phytochemistry 1982;21:1137-9.

37. Wu CC, Huang KF, Yang TY, Li YL, Wen CL, Hsu SL, et al. The Topoisomerase 1 inhibitor Austrobailignan-1 isolated from Koelreuteria henryi induces a G2/M-phase arrest and cell death independently of p53 in non-small cell lung cancer cells. PLoS One 2015; 10:e 0132052.

38. Hodroj MH, Jardaly A, Abi Raad S, Zouein A, Rizk S. Andrographolide potentiates the antitumor effect of topotecan in acute myeloid leukemia cells through an intrinsic apoptotic pathway. Cancer Manag Res 2018;10:1079.

39. Han J, Jeong HJ, Lee HN, Kwon YJ, Shin HM, Choi Y, et al. Erythroaustrobailignan-6 down-regulates HER2/EGFR/integrin $\beta 3$ expression via p38 activation in breast cancer. Phytomedicine 2017; 24:24-30.

40. Filleur F, Le Bail JC, Duroux JL, Simon A, Chulia AJ. Antiproliferative, anti-aromatase, anti-17 $\beta$-HSD and antioxidant activities of lignans isolated from Myristica argentea. Planta Med 2001;67:700-4.

41. Kim SJ, You J, Choi HG, Kim JA, Jee JG, Lee S. Selective inhibitory effects of machilin A isolated from Machilus thunbergii on human cytochrome P450 1A and 2B6. Phytomedicine 2015; 22:615-20.

42. Li G, Lee CS, Woo MH, Lee SH, Chang HW, Son JK. Lignans from the bark of Machilus thunbergii and their DNA topoisomerases I and II inhibition and cytotoxicity. Biol Pharm Bull 2004;27:1147-50.

43. Calliste CA, Kozlowski D, Duroux JL, Champavier Y, Chulia AJ, Trouillas P. A new antioxidant from wild nutmeg. Food Chem 2010;118:489-96.

44. Kim DY, Kim GW, Chung SH. Nectandrin A enhances the BMPinduced osteoblastic differentiation and mineralization by activation of p38 MAPK-smad signaling pathway. Korean J Physiol Pharmacol 2013;17:447-53; doi:10.4196/kjpp.2013.17.5.447

45. Nguyen PH, Le TVT, Kang HW, Chae J, Kim SK, Kwon K, et al. AMP-activated protein kinase (AMPK) activators from Myristica fragrans (nutmeg) and their anti-obesity effect. Bioorg Med Chem Lett 2010;20:4128-31.

46. Hattori M, Yang X, Miyashiro H, Namba T. Inhibitory effects of monomeric and dimeric phenylpropanoids from mace on lipid peroxidation in vivo and in vitro. Phytother Res 1993;7:395-401.

47. Jeng KCG, Hou RCW. Sesamin and sesamolin: nature's therapeutic lignans. Curr Enzyme Inhib 2005;1:11-20.

48. Shimizu S, Akimoto K, Shinmen Y, Kawashima H, Sugano M, Yamada H. Sesamin is a potent and specific inhibitor of $\Delta 5$ desaturase in polyunsaturated fatty acid biosynthesis. Lipids 1991;26:512-6; doi:10.1007/BF02536595

49. Choi J, Lee KT, Choi MY, Nam JH, Jung HJ, Park SK, et al. Antinociceptive anti-inflammatory effect of monotropein isolated from the root of Morinda officinalis. Biol Pharm Bull 2005;28: 1915-8.

50. Shin JS, Yun KJ, Chung KS, Seo KH, Park HJ, Cho YW, et al. Monotropein isolated from the roots of Morinda officinalis ameliorates proinflammatory mediators in RAW 264.7 macrophages and dextran sulfate sodium (DSS)-induced colitis via NF-kB inactivation. Food Chem Toxicol 2013;53:263-71.
51. Tyagi M, Bauri AK, Chattopadhyay S, Patro BS. Thiol antioxidants sensitize malabaricone $\mathrm{C}$ induced cancer cell death via reprogramming redox sensitive $\mathrm{p} 53$ and $\mathrm{NF}-\mathrm{\kappa B}$ proteins in vitro and in vivo. Free Radic Biol Med 2020;148:182-99.

52. Basak M, Mahata T, Chakraborti S, Kumar P, Bhattacharya B, Bandyopadhyay SK, et al. Malabaricone $\mathrm{C}$ attenuates nonsteroidal anti-inflammatory drug-induced gastric ulceration by decreasing oxidative/nitrative stress and inflammation and promoting angiogenic autohealing. Antioxid Redox Signal 2020;32:766-84; doi:10.1089/ ars.2019.7781

53. Sathya S, Amarasinghe NR, Jayasinghe L, Araya H, Fujimoto Y. Enzyme inhibitors from the aril of Myristica fragrans. S Afr J Bot 2020;130:172-6; doi:10.1016/j.sajb.2019.12.020

54. Suthisamphat N, Dechayont B, Phuaklee P, Prajuabjinda O, Vilaichone RKK, Itharat A, et al. Anti-Helicobacter pylori, anti-inflammatory, cytotoxic, and antioxidant activities of mace extracts from Myristica fragrans. Evid Based Complement Alternat Med 2020;2020:1-6; doi:10.1155/2020/7576818

55. Cheng YX, Zhou J, Tan NH. The chemical constituents of Parakmeria yunnanensis. Acta Bot Yunnanica 2001;23:352-6.

56. Hendrawati O, Woerdenbag HJ, Michiels PJA, Aantjes HG, Van Dam A, Kayser O. Identification of lignans and related compounds in Anthriscus sylvestris by LC-ESI-MS/MS and LC-SPE-NMR. Phytochemistry 2011;72:2172-9; doi:10.1016/j.phytochem.2011.08.009

57. Morikawa T, Hachiman I, Matsuo K, Nishida E, Ninomiya K, Hayakawa T, et al. Neolignans from the arils of Myristica fragrans as potent antagonists of $\mathrm{CC}$ chemokine receptor 3. J Nat Prod 2016;79:2005-13; doi:10.1021/acs.jnatprod.6b00262

58. Hattori M, Yang XW, Shu YZ, Kakiuchi N, Tezuka Y, Kikuchi T, et al. New constituents of the aril of Myristica fragrans. Chem Pharm Bull 1988;36:648-53.

59. Lee SU, Shim KS, Ryu SY, Min YK, Kim SH. Machilin A isolated from Myristica fragrans stimulates osteoblast differentiation. Planta Med 2009;75:152-7.

60. Chung TW, Kim EY, Han CW, Park SY, Jeong MS, Yoon D, et al. Machilin A inhibits tumor growth and macrophage M2 polarization through the reduction of lactic acid. Cancers (Basel) 2019;11:963.

61. da Silva Filho AA, Albuquerque S, e Silva MLA, Eberlin MN, Tomazela DM, Bastos JK. Tetrahydrofuran lignans from Nectandramegapotamica with trypanocidal activity. J Nat Prod 2004;67:42-5.

62. Park S, Lee DK, Yang CH. Inhibition of fos-jun-DNA complex formation by dihydroguaiaretic acid and in vitro cytotoxic effects on cancer cells. Cancer Lett 1998;127:23-8.

63. Yamauchi S, Masuda T, Sugahara T, Kawaguchi Y, Ohuchi M, Someya $\mathrm{T}$, et al. Antioxidant activity of butane type lignans, secoisolariciresinol, dihydroguaiaretic acid, and 7, 7'-oxodihydroguaiaretic acid. Biosci Biotechnol Biochem 2008; 72:2981-6.

64. Min BS, Cuong TD, Hung TM, Min BK, Shin BS, Woo MH. Inhibitory effect of lignans from Myristica fragranson LPS-induced no production in RAW264.7 cells. Bull Korean Chem Soc 2011;32:4059 62; doi:10.5012/bkcs.2011.32.11.4059

65. Ma CJ, Sung SH, Kim YC. Neuroprotective lignans from the bark of Machilus thunbergii. Planta Med 2004;70: 79-80.

66. Liang J, Huang B, Wang G. Chemical composition, antinociceptive and anti-inflammatory properties of essential oil from the roots of Illicium lanceolatum. Nat Prod Res 2012;26:1712-4.

67. Barboza JN, da Silva Maia Bezerra Filho C, Silva RO, Medeiros JVR, de Sousa DP. An overview on the anti-inflammatory potential and antioxidant profile of eugenol. Oxid Med Cell Longev 2018;2018:3957262; doi:10.1155/2018/3957262

68. Subarnas A, Apriyantono A, Mustarichie R. Identification of compounds in the essential oil of nutmeg seeds (Myristica fragrans Houtt.) that inhibit locomotor activity in mice. Int $\mathrm{J}$ Mol Sci 2010;11:4771-81. 
69. Cho SJ, Kwon HS. Tyrosinase inhibitory activities of safrole from Myristica fragrans Houtt. J Appl Biol Chem 2015;58:295-301; doi:10.3839/jabc.2015.047

70. Purushothaman KK, Sarada A, Connolly JD. Malabaricones A-D, novel diarylnonanoids from Myristica malabarica Lam (Myristicaceae). J Chem Soc Perkin 1 1977;5:587-8. doi:10.1039/ P19770000587

71. Kang J, Tae N, Min BS, Choe J, Lee JH. Malabaricone C suppresses lipopolysaccharide-induced inflammatory responses via inhibiting ROS-mediated Akt/IKK/NF- $\mathrm{BB}$ signaling in murine macrophages. Int Immunopharmacol 2012;14:302-10.

72. Paul A, Das J, Das S, Samadder A, Khuda-Bukhsh AR. Anticancer potential of myricanone, a major bioactive component of Myrica cerifera: novel signaling cascade for accomplishing apoptosis. J Acupunct Meridian Stud 2013;6:188-98.

73. Maity B, BanerjeeD, Bandyopadhyay SK, Chattopadhyay S, Regulation of arginase/nitric oxide synthesis axis via cytokine balance contributes to the healing action of malabaricone $\mathrm{B}$ against indomethacin-induced gastric ulceration in mice. Int Immunopharmacol 2009;9:491-8.

74. Rangkaew N, Suttisri R, Moriyasu M, Kawanishi K. A new acyclic diterpene acid and bioactive compounds from Knema glauca. Arch Pharm Res 2009;32:685-92; doi:10.1007/s12272-009-1506-5

75. Morrison M, van der Heijden R, Heeringa P, Kaijzel E, Verschuren L, Blomhoff R, et al. Kleemann, epicatechin attenuates atherosclerosis and exerts anti-inflammatory effects on diet-induced human-CRP and NFkB in vivo. Atherosclerosis 2014;233:149-56.

76. Sawadjoon S, Kittakoop P, Kirtikara K, Vichai V, Tanticharoen $\mathrm{M}$, Thebtaranonth Y. Atropisomeric myristinins: selective COX-2 inhibitors and antifungal agents from Myristica cinnamomea. J Org Chem 2002;67:5470-5.

77. Rysz J, Bartnicki P, Błaszczak R, Kujawski K, Ciałkowska-Rysz A, Olszewski R, et al. Anti-inflammatory action of myoinositol in renal insufficiency. Pol Merkur Lekarski 2006;20:180-3.
78. Srinivasulu C, Ramgopal M, Ramanjaneyulu G, Anuradha CM, Kumar CS. Syringic acid (SA)-a review of its occurrence, biosynthesis, pharmacological and industrial importance. Biomed Pharmacother 2018;108:547-57.

79. Ninomiya K, Hayama K, Ishijima SA, Maruyama N, Irie H, Kurihara $\mathrm{J}$, et al. Suppression of inflammatory reactions by terpinen-4-ol, a main constituent of tea tree oil, in a murine model of oral candidiasis and its suppressive activity to cytokine production of macrophages in vitro. Biol Pharm Bull 2013;36:838-44.

80. Liu S, Zhao Y, Cui HF, Cao CY, Zhang YB. 4-Terpineol exhibits potent in vitro and in vivo anticancer effects in Hep-G2 hepatocellular carcinoma cells by suppressing cell migration and inducing apoptosis and sub-G1 cell cycle arrest. J Buon 2016;21:1195-202.

81. Zhao G, Wang X, Gao H. Isolation and identification of chemical constituents from processed Myristica fragrans Houtt. J Mod Chinese Med 2011;11.

82. Zhao C, She T, Wang L, Su Y, Qu L, Gao Y, et al. Daucosterol inhibits cancer cell proliferation by inducing autophagy through reactive oxygen species-dependent manner. Life Sci 2015;137:37-43.

\section{How to cite this article:}

Marulasiddaswamy KM, Nuthan BR, ChannarayapatnaRamesh S, Bajpe SN, Kumara KKS, Sekhar S, Kini KR. HRLC-MS based profiling of phytochemicals from methanol extracts of leaves and bark of Myristica dactyloides Gaertn. from Western Ghats of Karnataka, India. J Appl Biol Biotech 2021; 9(05):124-135. 